\title{
Characterization of acetate transport in colorectal cancer cells and potential therapeutic implications
}

\author{
Suellen Ferro ${ }^{1,2}$, João Azevedo-Silva ${ }^{1}$, Margarida Casal' $^{1}$, Manuela Côrte-Real ${ }^{1}$, \\ Fatima Baltazar ${ }^{3,4}$, Ana Preto ${ }^{1}$ \\ ${ }^{1}$ CBMA - Centre of Molecular and Environmental Biology, Department of Biology, University of Minho, Campus de Gualtar, \\ Braga, Portugal \\ ${ }^{2}$ ICBAS - Institute of Biomedical Sciences Abel Salazar, University of Porto, Porto, Portugal \\ ${ }^{3}$ Life and Health Sciences Research Institute (ICVS), School of Health Sciences, University of Minho, Braga, Portugal \\ ${ }^{4}$ ICVS/3B's - PT Government Associate Laboratory, Braga/Guimarães, Portugal \\ Corresponding to: Ana Preto, email: apreto@bio.uminho.pt \\ Keywords: colorectal cancer, monocarboxylate transporters, short-chain fatty acids, acetate, 3-bromopyruvate \\ Received: May 05, $2016 \quad$ Accepted: September 02, $2016 \quad$ Published: September 21, 2016
}

\section{ABSTRACT}

Acetate, together with other short chain fatty acids has been implicated in colorectal cancer (CRC) prevention/therapy. Acetate was shown to induce apoptosis in CRC cells. The precise mechanism underlying acetate transport across CRC cells membrane, that may be implicated in its selectivity towards CRC cells, is not fully understood and was addressed here. We also assessed the effect of acetate in CRC glycolytic metabolism and explored its use in combination with the glycolytic inhibitor 3-bromopyruvate (3BP). We provide evidence that acetate enters CRC cells by the secondary active transporters MCT1 and/or MCT2 and SMCT1 as well as by facilitated diffusion via aquaporins. CRC cell exposure to acetate upregulates the expression of MCT1, MCT4 and CD147, while promoting MCT1 plasma membrane localization. We also observed that acetate increases CRC cell glycolytic phenotype and that acetateinduced apoptosis and anti-proliferative effect was potentiated by 3BP. Our data suggest that acetate selectivity towards CRC cells might be explained by the fact that aquaporins and MCTs are found overexpressed in CRC clinical cases. Our work highlights the importance that acetate transport regulation has in the use of drugs such as 3BP as a new therapeutic strategy for CRC.

\section{INTRODUCTION}

Colorectal cancer (CRC) is one of the most common cancers and cause of cancer death in developed countries, highlighting the need of novel strategies for prevention/ therapy of CRCs [1].

Short chain fatty acids (SCFA), namely acetate, propionate and butyrate are produced by bacterial fermentation of dietary fiber that escape absorption in the small intestine. These compounds are produced in a millimolar ratio of approximately 60:20:20, respectively [2], being a major source of energy for colonocytes. It was shown that in vivo administration of Propionibacterium freudenreichii significantly increased apoptosis in colon cells damaged with a carcinogenic agent (1,2-dimethylhydrazine) without affecting the survival of healthy normal colonocytes [3, 4]. We and others, previously established that acetate affects CRC cells survival in vitro [5-9]. We showed that acetate inhibits CRC cell proliferation, induces apoptosis, promotes lysosomal membrane permeabilization with release of cathepsin D, which is associated with an autophagyindependent degradation of damaged mitochondria [5, 9]. The reason for acetate selectivity towards transformed colon cells without affecting normal colon cells is still elusive.

To exert their cellular effect, SCFA must be transported across the plasma membrane [10]. SCFA (including acetate) can either enter normal colon cells through passive diffusion or by membrane transporters mainly monocarboxylate transporter-1 (MCT1) and sodium-coupled monocarboxylate transporter SMCT1 
$[1,11]$. In CRC cells, the majority of the reports studied butyrate transport and showed that MCT1 is the main implicated transporter $[1,12,13]$. However, the precise mechanism of acetate transport in CRC cells has not been characterized and might contribute to its selectivity to CRC cells.

MCT overexpression has been described in several cancer types, including CRC, being involved in the maintenance of glycolytic metabolism by mediating lactate export $[14,15]$. MCTs have been explored as therapeutic targets [16] and as mediators of the entry of drugs such as the anticancer compound 3-bromopyruvate (3BP) $[14,17]$.

Since acetate is the most relevant SCFA produced in the colon, although less studied, we aimed herein to characterize the mechanism of acetate transport across the plasma membrane of CRC cells. We also intended to evaluate the effect of acetate on glycolytic metabolism, as well as to explore the use of acetate in combination with $3 \mathrm{BP}$ as a novel therapeutic strategy in CRC.

\section{RESULTS}

\section{Kinetics and energetics of acetate transport by colorectal cancer cells}

The initial uptake rates of $\left[{ }^{14} \mathrm{C}\right]$ acetate were evaluated in HCT-15 and RKO cell lines at pH 6.0 (Figure $1 \mathrm{a}$ and $1 \mathrm{~b}$ ). The analysis of non-linear regression showed that in HCT-15 cells, acetate transport follows a second order kinetics with an affinity constant $\left(K_{m}\right)$ of $1.97 \pm 0.57$ $\mathrm{mM}$ and a transport capacity $\left(V_{\max }\right)$ of $62 \pm 9 \mathrm{nmol} / \mathrm{mg}$ of protein/min. In RKO cells, acetate transport follows a first order kinetics with a diffusion constant of $5.19 \pm 0.16 \mu \mathrm{L} /$ $\mathrm{mg}$ of protein $/ \mathrm{min}$.

To evaluate the energetics of $\left[{ }^{14} \mathrm{C}\right]$ acetate transport we tested the influence of agents known to disrupt different ion membrane electrochemical potentials such as CCCP (a protonophore which disrupts both the proton and the electrical gradient), monensin (an ionophore that specifically disrupts sodium gradient) and valinomycin (an ionophore which preferentially affects potassium and sodium gradient across biological membranes). We also tested the inhibition of acetate transport using inhibitors of monocarboxylate transporters such as $\mathrm{CHC}$ (inhibitor of MCT1 and SMCT1) [18, 19], DIDS (inhibitor of MCTs and anion exchangers) [20] and AR-C155858 (inhibitor of MCT1 and MCT2) [21] (Figure 1c).

Our results showed that CCCP inhibited significantly acetate transport in both HCT-15 (71\%) and RKO (52\%) cells; monensin also inhibited acetate uptake in HCT$15(78 \%)$ and RKO (36\%), and valinomycin presented only a small inhibitory effect in both cell lines $(22 \%$ and $21 \%$ in in HCT-15 and RKO cells, respectively). The results obtained with CCCP inhibitory effects led us to conclude that acetate transport in CRC cells is sensitive to the plasma membrane potential. Moreover, monensin inhibition indicates that sodium gradient is also important in this process. Concerning valinomycin inhibition, the transport of acetate is less affected suggesting that potassium gradient might not be involved but rather its effect might be due to the disruption of the sodium gradient, taking into account the results with monensin.

Regarding general MCTs inhibitors: $\mathrm{CHC}$ inhibited both HCT-15 (30\%) and RKO cells (35\%), while DIDS and AR-C155858 had no inhibitory effect suggesting a possible contribution of at least SMCT1 in acetate uptake in CRC cells.

The transport of acetate in normal colon cells has also been shown to occur through passive transport [11]. This transport component may be relevant in RKO cells, since acetate transport followed a first order kinetics and was less affected by CCCP and monensin than HCT-15 cells. A possible contribution of aquaporins to acetate uptake could also explain the acetate kinetics in RKO cells. Aquaporins are small transmembrane channel proteins that allow the passage of water and other small solutes, such as glycerol and some ions, through cell membranes in response to osmotic gradient $[22,23]$. Furthermore, aquaporin 1 and aquaporin 3 are upregulated in CRC cells and their expression was correlated with tumor growth, invasiveness and metastasis [22, 24]. Consequently, we used $\mathrm{HgCl}_{2}$, which is described as an inhibitor of aquaporin activity (especially of certain classes such as aquaporin 1 and aquaporin 3) $[23,25]$ to verify if acetate transport into CRC cells could also be mediated through passive transport by aquaporins. Interestingly, $\mathrm{HgCl}_{2}$ inhibited acetate uptake in HCT-15 (51\%) and RKO (56\%) cells, suggesting the contribution of aquaporins to acetate transport in both CRC cell lines (Figure 1c). We further investigated if inhibition of acetate transport by $\mathrm{HgCl}_{2}$ in HCT-15 and RKO cells was independent of the inhibition detected for CCCP or monensin. To this end we assess the effect of the combined used of the inhibitors. However, in order to avoid saturation and enable the evaluation of the combined effect of the different drugs, the concentrations of the inhibitors used in these combination experiments were lower than the concentrations used in the experiments were they were tested alone (Figures 1 and 3). Our results showed that while the use of CCCP $(1 \mu \mathrm{M}), \mathrm{HgCl}_{2}(5 \mu \mathrm{M})$ and monensin $(20 \mu \mathrm{M})$ (Figure $2 \mathrm{a})$ caused inhibition of acetate transport in HCT-15 cells of $34 \%, 37 \%$, and $69 \%$, respectively, the dual combination of $\mathrm{CCCP} / \mathrm{HgCl}_{2}, \mathrm{HgCl}_{2} /$ monensin, and $\mathrm{CCCP} /$ monensin resulted in an inhibition of $56 \%, 76 \%$ and $75 \%$, respectively.

In RKO cells (Figure 2b) acetate uptake inhibition by $\mathrm{CCCP}, \mathrm{HgCl}_{2}$ and monensin was $37 \%, 28 \%$ and $68 \%$, respectively, but when $\mathrm{CCCP} / \mathrm{HgCl}_{2}$ or monensin/ $\mathrm{HgCl}_{2}$ were combined acetate transport inhibition was $46 \%$ and $81 \%$, respectively.

Altogether these results point to the involvement of a secondary active transport dependent on the 
electrochemical $\mathrm{Na}^{+}$gradient (probably involving SMCT1) and a passive transport by a facilitated diffusion component mediated through aquaporins in CRC cells.

\section{Acetate upregulates the expression of MCT1, MCT4 and CD147 in colorectal cancer cells}

We further assessed the kinetics and energetics of acetate uptake in cell cultures exposed with levels of acetate mimicking its intestinal microenvironment concentration. To test this hypothesis, HCT-15 and RKO cells were exposed for 48 hours to $\mathrm{IC}_{30}$ and $\mathrm{IC}_{50}$ doses of acetate previously determined by us [5].

a

HCT-15

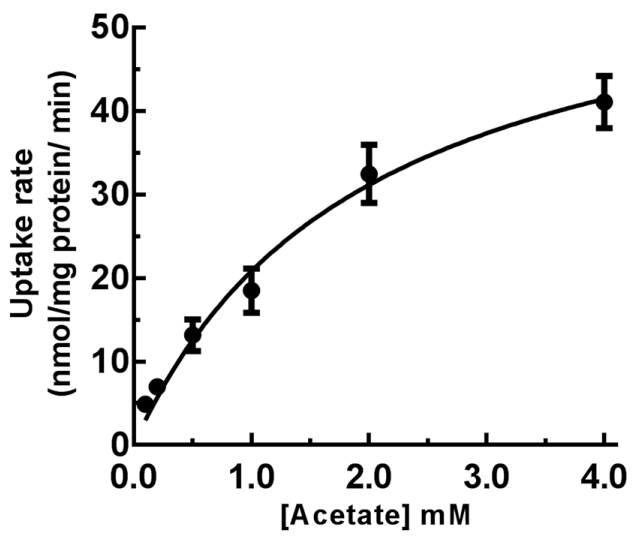

Upon incubation with $\mathrm{IC}_{30}$ during 48 hours we could observe that acetate transport, in contrast to cells non-exposed to acetate, was significantly inhibited by AR-C155858 in HCT-15 and RKO cells (29\% and 23\%, respectively). This specific inhibitory effect suggests the involvement of MCT1 and/or MCT2 in acetate uptake under these conditions. In addition, the inhibitory pattern for $\mathrm{CCCP}$, monensin and $\mathrm{HgCl}_{2}$ was not altered (Figure 3). The relative values of acetate transport were expressed as percentage in relation to the control (without inhibitor) in each condition. Moreover, no significant alteration in acetate uptake capacity was observed between cells treated and untreated with acetate (data not shown). b

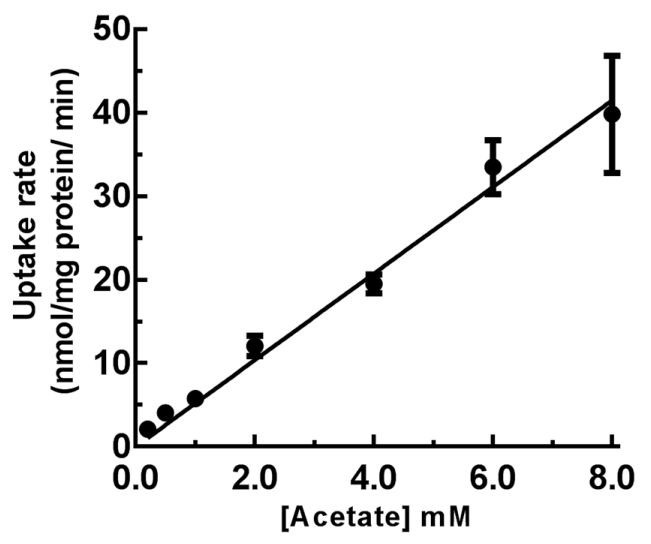

C

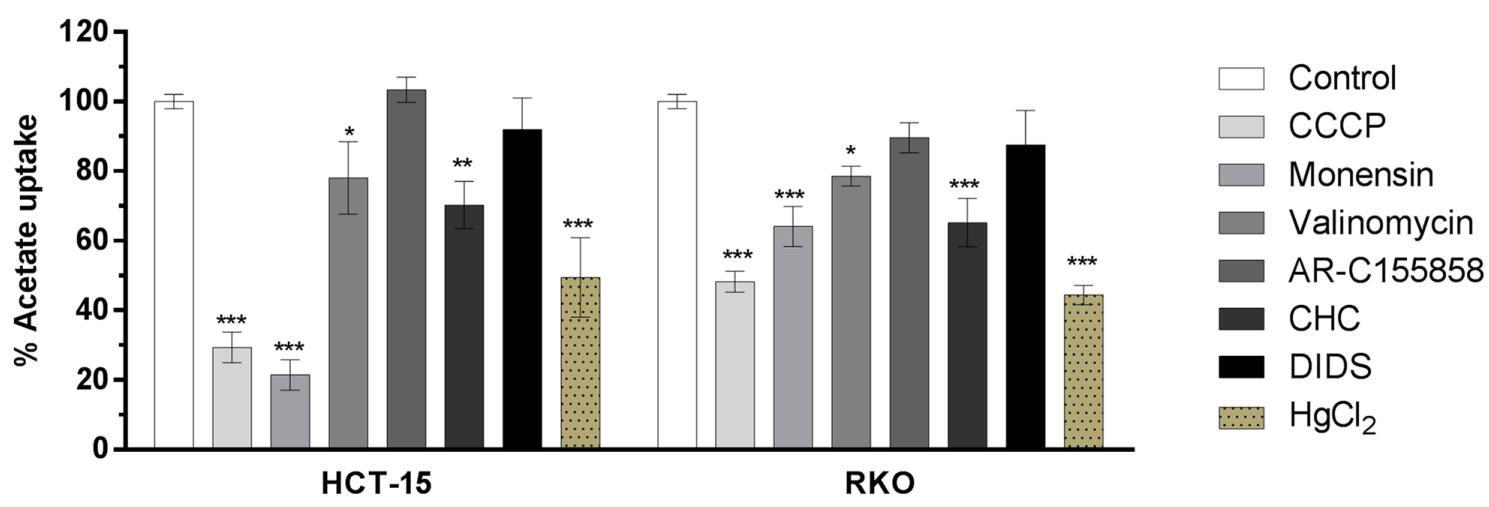

Figure 1: Characterization of acetate uptake in CRC cells. a, b. Plots of the initial uptake rates of labeled acetate, as a function of the acid concentration at pH 6.0 in HCT-15 (a) and RKO (b). Kinetic parameters, as affinity constant $\left(K_{m}\right)$ and transport capacity $\left(V_{\text {max }}\right)$ or Diffusion constant $\left(K_{d}\right)$ for the uptake of acetate were based on the non-linear regression for the Michaelis-Menten equation $\mathrm{f}[\mathrm{V}]=(\mathrm{Vmax}$ $\mathrm{x}[$ Acetate] $) /\left(\mathrm{Km}+[\right.$ Acetate] $)$ and Passive diffusion equation $\mathrm{f}[\mathrm{V}]=\mathrm{Kd}$.[Acetate]. In HCT-15 the transporter system shows a $K_{m}$ of $1.97 \pm$ $0.57 \mathrm{mM}$ and a $V_{\max }$ of $62 \pm 9 \mathrm{nmol} / \mathrm{mg}$ of protein/ min. In RKO acetate enters cells by passive diffusion with a $K_{d}$ of $5.19 \pm 0.16$. (c) Effect of CCCP $(100 \mu \mathrm{M})$, Monensin $(100 \mu \mathrm{M})$, Valinomycin $(100 \mu \mathrm{M})$, AR-C155858 $(1 \mu \mathrm{M}), \mathrm{CHC}(10 \mathrm{mM}), \mathrm{DIDS}(1 \mathrm{mM})$ and HgCl $(100 \mu \mathrm{M})$ in the uptake of $1 \mathrm{mM}$ of acetate. Statistical analysis was performed by two-way ANOVA: ***, ** and * indicate significant differences with a respective $\mathrm{P}$-values of $<0.001,<0.01$ and $<0.05$ ( $\mathrm{n}=3$ ). 
We further assessed the expression profile of SMCT1, MCT1, MCT4, MCT2 and of the chaperone cluster of differentiation CD147 (an important protein for MCT activity, including MCT1 and MCT4) in response to acetate (Figure 4). Extracts of CRC cells exposed to $\mathrm{IC}_{30}$ and $\mathrm{IC}_{50}$ acetate doses for 24 and 48 hours, were analyzed by Western blot. We found that the expression of SMCT1 and MCT2 was not affected by exposure to acetate. In contrast the expression of MCT1 and MCT4 was enhanced only after 48 hours, in both cell lines compared to the negative control. Furthermore, the chaperone CD147, was present in both fully-glycosylated (FG) and core-glycosylated (CG) forms in both CRC cell lines after 48 hours of acetate treatment. We have also observed that in both cells the expression of GLUT-1 transporter, responsible for basal glucose transport [26],

a

HCT-15

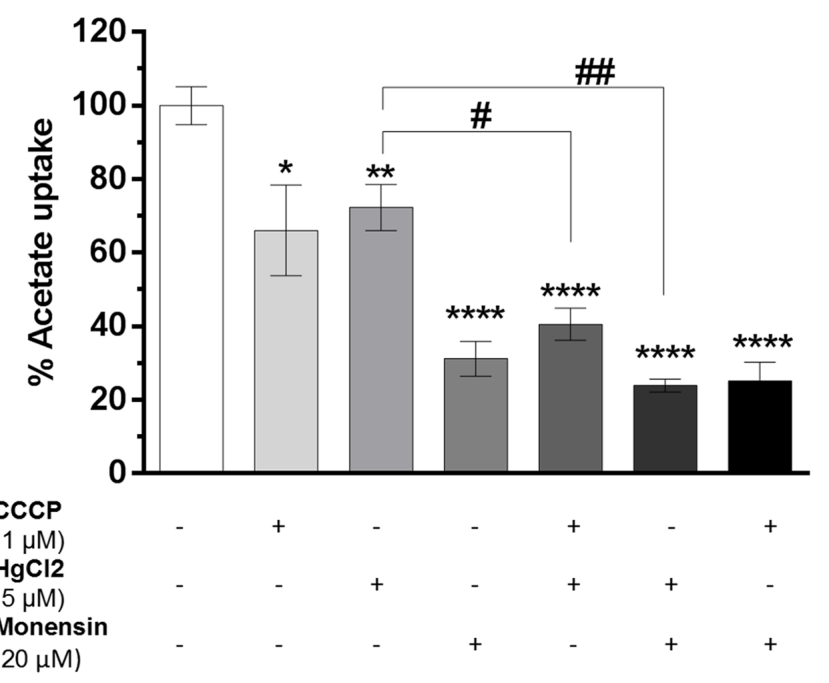

b

RKO

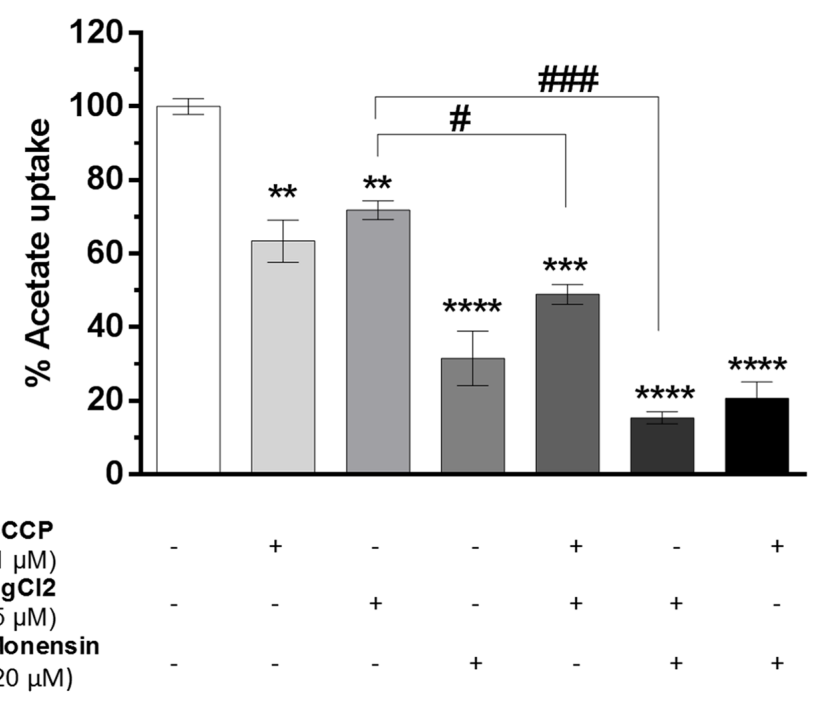

Figure 2: Inhibition of $1 \mathrm{mM}$ of acetate uptake by $\mathrm{CCCP}(1 \mu \mathrm{M}), \mathrm{HgCl}_{2}(5 \mu \mathrm{M})$ and Monensin $(20 \mu \mathrm{M})$ alone or in combination in HCT-15 a. and RKO b. cells. Statistical analysis was performed by two-way ANOVA (n=3): *******,** and * indicate significant differences with a respective P-values of $<0.0001<0.001,<0.01$ and $<0.05$ compared to negative control and \#\#\#, \#\#, \# indicates $\mathrm{P}$-values of $<0.001,<0.01$ and $<0.05$ compared to $\mathrm{HgCl}_{2}$ inhibition alone with combination $\left(\mathrm{HgCl}_{2}\right.$ with $\mathrm{CCCP}$ and $\mathrm{HgCl}_{2}$ with Monesin). 
was not affected. Overall our results suggest that in CRC cells acetate upregulates the expression of MCT1, MCT4 and CD147.

\section{Acetate induces MCT1 plasma membrane localization in colorectal cancer cells}

We further analyzed by immunofluorescence the changes induced by acetate on the cellular localization of MCT1, MCT4 and CD147. We could observe that acetate leads to an elevated expression of these transporters and an increase in MCT1 localization at the plasma membrane in comparison to the cytoplasm in both cell lines (Figure 5). Moreover, we found no differences between MCT4 and CD147 co-localization after acetate treatment. Our results suggest that in the presence of acetate, at concentrations similar to those observed in the colon, there is an increase in MCT1 localization at the plasma membrane, which might enhance the membrane transport of acetate by MCT1 in CRC cells.

\section{Acetate treatment perturbs the glycolytic metabolism and 3-bromopyruvate potentiates acetate-induced apoptosis in colorectal cancer cells}

We therefore wondered if acetate might induce metabolic changes. HCT-15 and RKO cells were exposed to $\mathrm{IC}_{30}$ and $\mathrm{IC}_{50}$ doses of acetate and the relative rate of glucose consumption and extracellular lactate production were measured at 3, 6, 12 and 24 hours in triplicate and normalized to cell biomass determined by SRB at T0 (Figure 6a). None of these conditions showed alteration in cell proliferation. We found that $\mathrm{CRC}$ cells in response

HCT-15

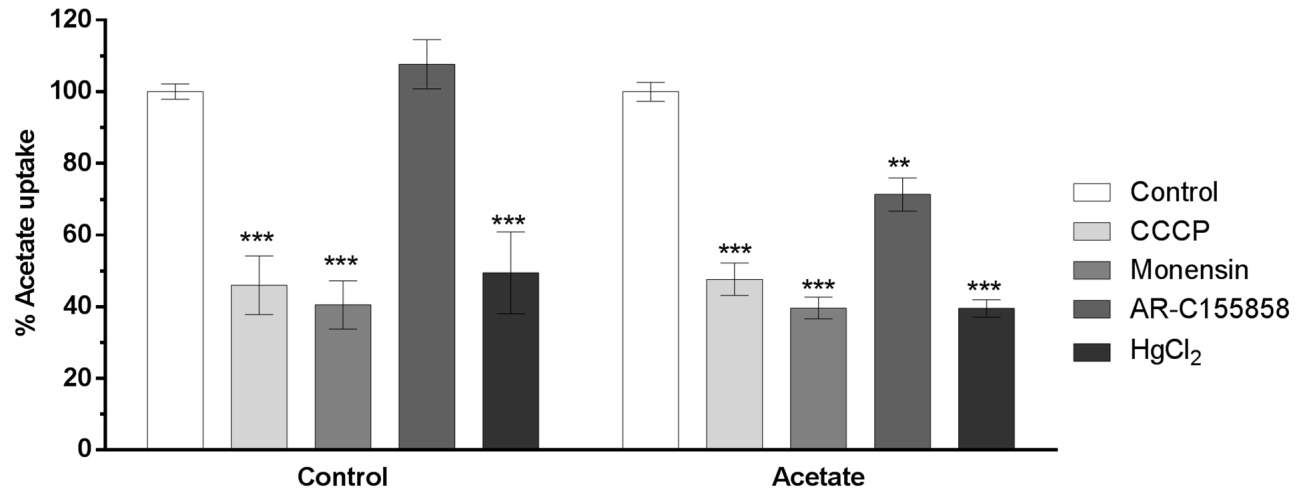

RKO

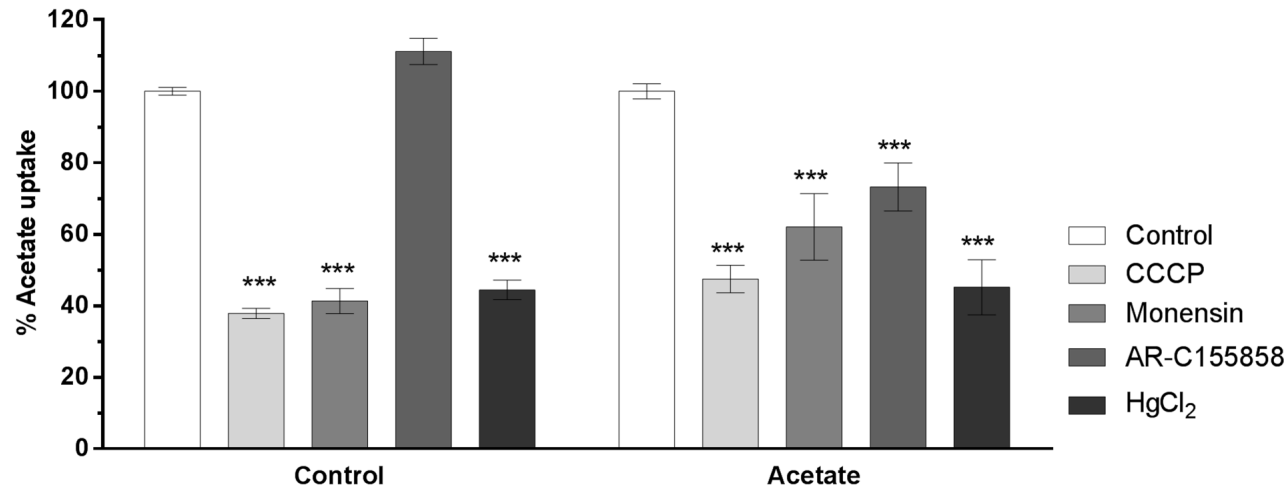

Figure 3: Inhibition of acetate $(1 \mathrm{mM})$ uptake in HCT-15 and RKO cell lines treated with $\mathrm{IC}_{30}$ of acetate for $48 \mathrm{~h}$ with CCCP $(100 \mu \mathrm{M})$, Monensin $(100 \mu \mathrm{M})$, AR-C155858 $(1 \mu \mathrm{M})$ and $\mathrm{HgCl}_{2}(100 \mu \mathrm{M})$. Statistical analysis was performed by twoway ANOVA: $* * *, * *$ and $*$ indicate significant differences with a respective $\mathrm{P}$-values of $<0.001,<0.01$ and $<0.05(\mathrm{n}=3)$. 
to acetate exhibited a higher consumption of glucose $(\mathrm{p}>$ $0.05)$ and lactate production rates $(\mathrm{p}>0.05 ; \mathrm{p}>0.01)$ up to 24 hours in a dose-dependent manner (Figure 6b, 6c).

We have previously showed that butyrate at concentration ranging from at $500-10.000 \mu \mathrm{M}$ increased MCTs expression and localization to the plasma membrane sensitizing breast cancer cells to the glycolytic inhibitor 3-bromopyruvate (3BP) [17, 27]. Since acetate, like butyrate exhibited a similar effect in CRC cells regarding the expression of MCT1 and MCT4 and the increased CRC cell glycolytic phenotype, we hypothesized that acetate could also sensitize CRC cells to 3BP. To explore this hypothesis, we studied the combined use of acetate with 3BP. We performed colony formation assays (CFA) in CRC cells treated with $3 \mathrm{BP} \mathrm{IC}_{25}$ and $\mathrm{IC}_{50}$ alone or in combination with acetate $\mathrm{IC}_{50}$. We found that the combined treatment $\left(\mathrm{IC}_{25}\right.$ of $3 \mathrm{BP} / \mathrm{IC}_{50}$ of acetate and $\mathrm{IC}_{50}$ of $3 \mathrm{BP} / \mathrm{IC}_{50}$ of acetate) decreased cell proliferation (number of colonies formed) in both CRC cell lines (Figure 7a). Analysis of cell proliferation by SRB assay (Figure 7b) showed that for all conditions tested, except for the $\mathrm{IC}_{25}$ of $3 \mathrm{BP}$, there was a significant reduction in the proliferation of HCT-15 and $\mathrm{RKO}$. The combination of $\mathrm{IC}_{25} \mathrm{IC}_{50} 3 \mathrm{BP}$ with the $\mathrm{IC}_{50}$ acetate significantly potentiates the effect of acetate per se

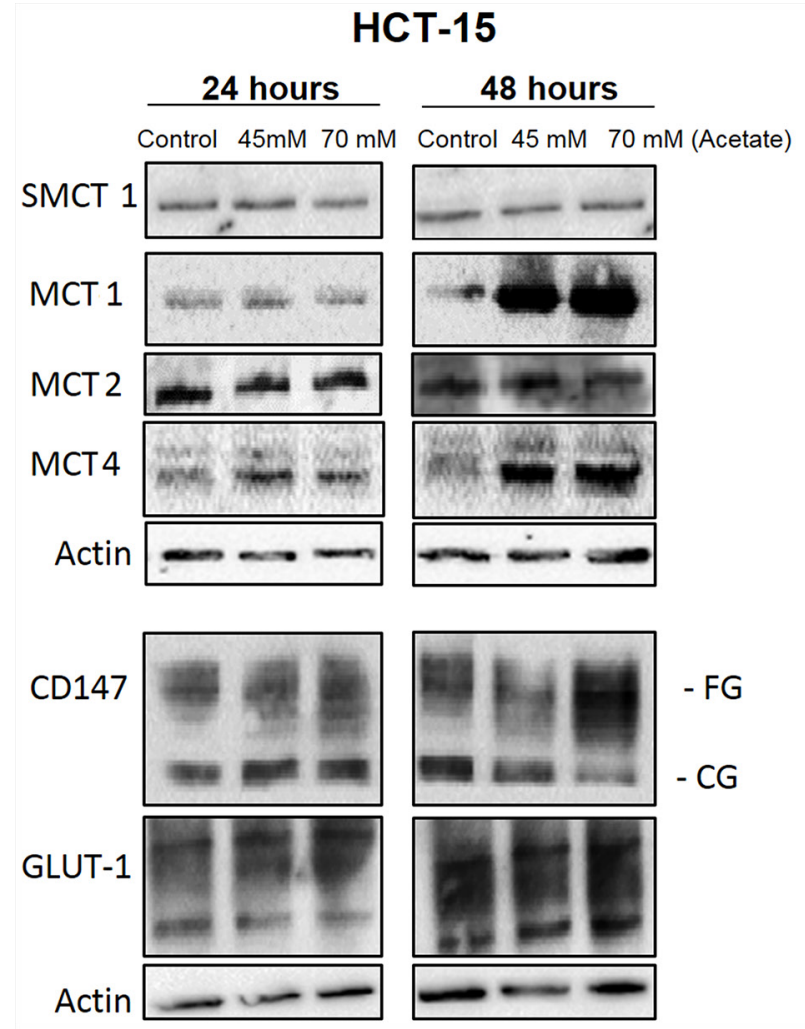

in the inhibition of cell proliferation $(p>0.01$ and $p>$ 0.0001 , respectively) in both CRC cell lines.

We show that treatment with $3 \mathrm{BP}$ alone induced a significant increase $(p>0.05$ and $p>0.01)$ in cells stained with AV/PI in a dose-dependent manner in both CRC cells. In addition, we found that the combined treatment of $3 \mathrm{BP}$ and acetate $\left(\mathrm{IC}_{25}\right.$ of $3 \mathrm{BP} / \mathrm{IC}_{50}$ of acetate and $\mathrm{IC}_{50}$ of $3 \mathrm{BP} /$ $\mathrm{IC}_{50}$ of acetate) potentiates apoptosis, as the number of early and late apoptotic cells showed a significant increase in comparison with acetate alone $(\mathrm{p}>0.01$ and $\mathrm{p}>0.001)$ in both CRC cells. In summary, our results show that 3BP in combination with acetate increased the anti-proliferative effect of acetate and potentiates acetate-induced apoptosis in CRC cells.

\section{DISCUSSION}

Acetate is the main SCFA produced by Propionibacterium which normally reside in the human colon. It has been shown that the concentration of SCFA, including acetate, is modulated by numerous factors such as intestinal microbial community, diet, age, medication and intestinal diseases [28, 29]. The colonic SCFA acetate can be found in the gut at considerably high

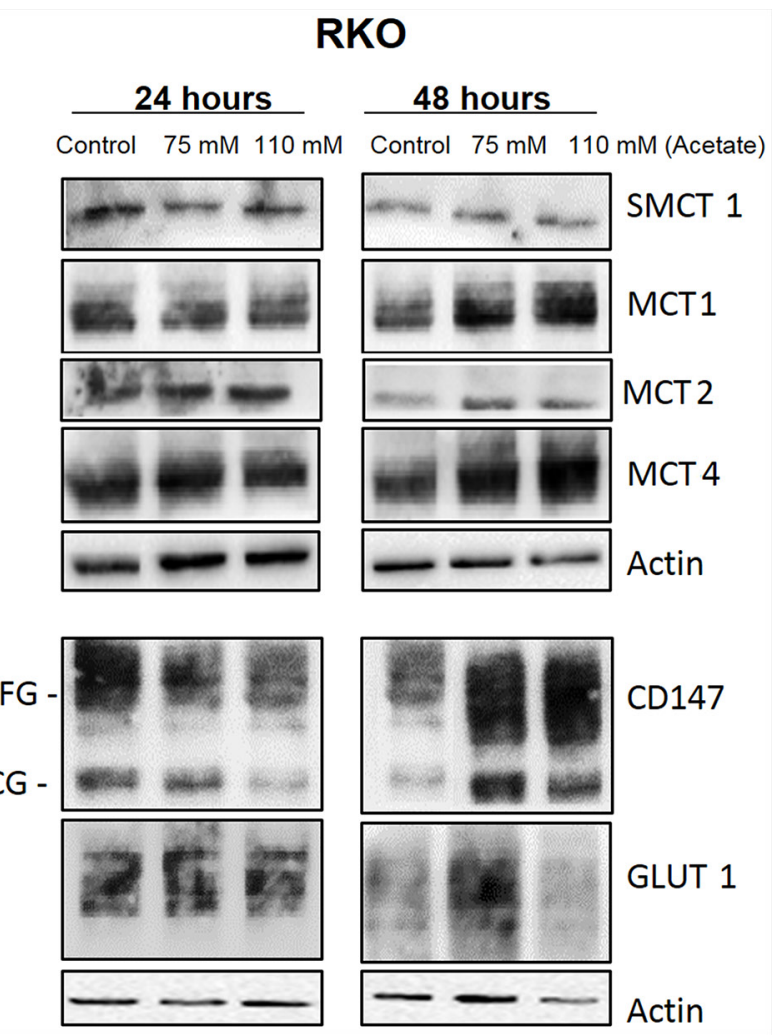

Figure 4: Characterization of MCTs expression and other glycolytic markers in CRC cells after acetate treatment. HCT-15 and RKO cells were incubated with acetate ( $45 \mathrm{mM}$ and $70 \mathrm{mM}$ for HCT-15 cells; $75 \mathrm{mM}$ and $110 \mathrm{mM}$ for RKO cells, respective doses for the $\mathrm{IC}_{30}$ and $\mathrm{IC}_{50}$ ) or with fresh medium (as negative control) for 24 and 48 hours. Western blotting images of the SMCT1, MCT1, MCT4, MCT2, CD147 and GLUT-1 expression. $\beta$-actin was used as loading control. A representative experiment of at least three independent experiments is shown. 
concentrations, which physiological levels range from $40-80 \mathrm{mM}$, although there is a variation along the human colon and specially after a dietary fiber-containing meal $[8,30]$.

SCFAs, including acetate, show anti-tumorigenic properties in CRC cells and transformed colon cells, while exerting a protective role in normal colonic crypts
$[3,4]$. The cellular and molecular mechanisms underlying acetate-induced apoptosis in CRC cells have been studied $[5,9,31]$, however the reason for acetate selectivity towards transformed colon and CRC cells is still elusive. To exert its effects and access the cellular targets, acetate has to be transported across the plasma membrane of colon cells. Studies on SCFA in normal colon and CRC

\section{MCT1}

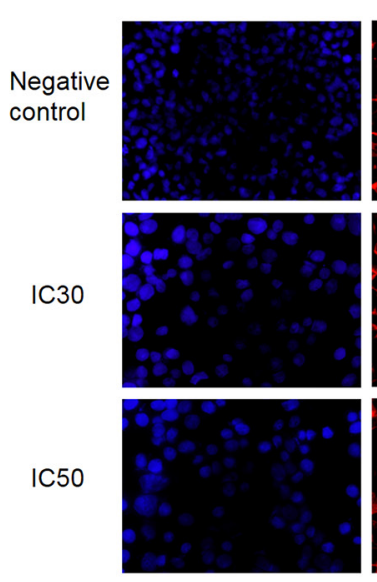

MCT 4

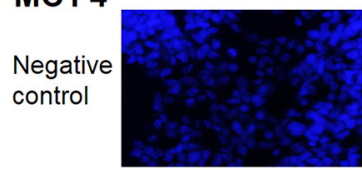

IC30

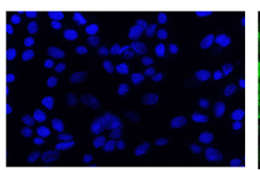

IC50

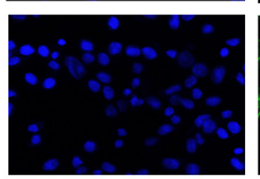

CD147
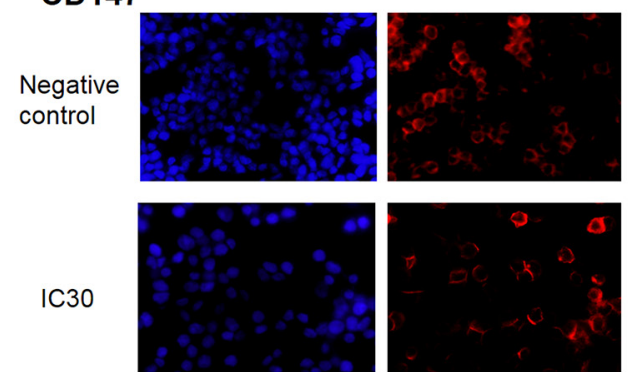

IC50

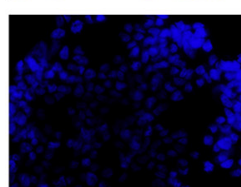

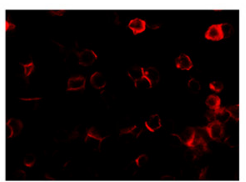

HCT-15
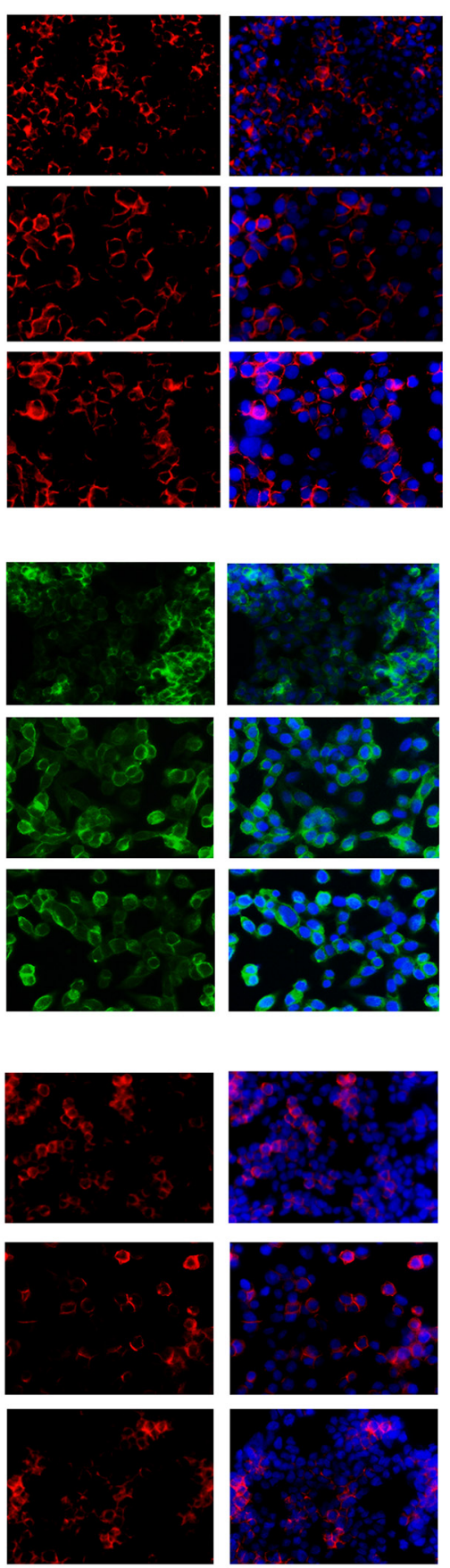
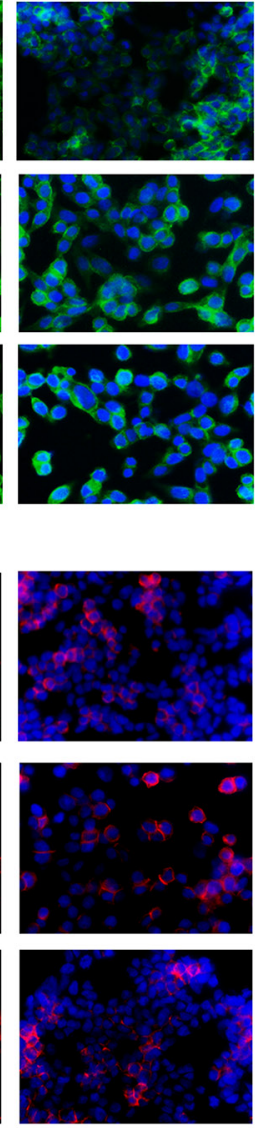

RKO
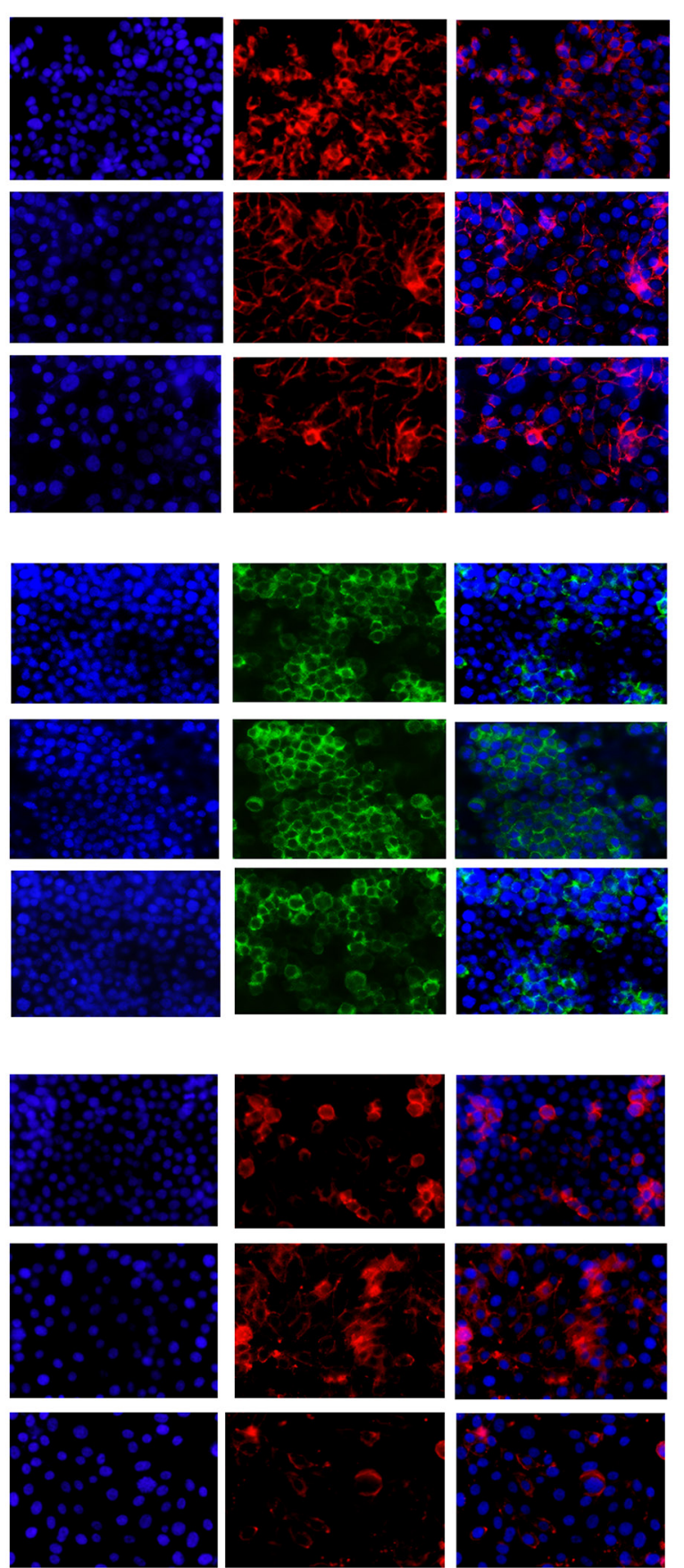

Figure 5: Localization of MCT1, MCT4 and CD147 in CRC cells after acetate treatment. HCT-15 and RKO cells were incubated with acetate ( $45 \mathrm{mM}$ and $70 \mathrm{mM}$ for HCT-15 cells; $75 \mathrm{mM}$ and $110 \mathrm{mM}$ for RKO cells, respective doses for the $\mathrm{IC}_{30}$ and $\mathrm{IC}_{50}$ ) or with fresh medium (as negative control) for 48 hours. Representative images of immunofluorescence are shown (400× magnification). 
cells have been focused mainly on butyrate transport [1, $12,13]$, being the information on acetate transport quite scarce.

In an attempt to characterize the transport of acetate across CRC cells, here we carried out kinetics and energetic studies of acetate uptake. We demonstrated that at pH 6.0 (similar to the gut environment), acetate transport across CRC cell membrane is strongly inhibited by monensin and CHC but not by DIDS and AR-C155858, supporting the contribution of SMCT1 in acetate transport in CRC cells. SMCT1 is an active unidirectional transporter that mediates lactate uptake and is expressed abundantly in the apical membrane of the colon $[12,32,33]$. Our results on acetate transport are in accordance with several reports showing that SMCT1 transports monocarboxylic acids such as butyrate, 3BP and dichloroacetate in cancer cells [17, 34-36]. On the other hand, some reports have demonstrated that SMCT1 is silenced in some CRC by DNA methylation $[1,12,34$, 36], conferring a selective advantage to escape butyrateinduced cell death [12, 37]. This could also be true for acetate as here we showed that in CRC cells expressing SMCT1, this transporter is relevant for acetate uptake and consequently for the acetate-induced apoptosis effect in CRC cells.

Acetate was also demonstrated to enter normal colon cells by passive transport [11]. Our experimental data suggest that diffusion through aquaporins, small transmembrane channel proteins [24, 38, 39], also contributes to acetate uptake, since acetate transport was inhibited by $\mathrm{HgCl}_{2}$. The contribution of aquaporins to acetate uptake could explain the different kinetics of acetate transport in the CRC cells studied. Indeed, acetate transport follows a first order kinetics in $\mathrm{RKO}$ cells, being less affected by CCCP or monensin than HCT-15 cells, likely due to a higher contribution of aquaporins for acetate transport in RKO cells. To the best of our knowledge, this is the first report suggesting that aquaporins, found upregulated in different types of cancer including CRC $[22,24,40]$, might play a role in acetate transport in CRC cells.

Monocarboxylate transporters 1 to 4 (MCT 1-4) are proton symporters, involved in the uptake and/or efflux of pyruvate, lactate, ketone bodies and SCFA through the plasma membrane $[11,15]$. We investigated if exposure to acetate could regulate its transport through MCTs.

\section{a}
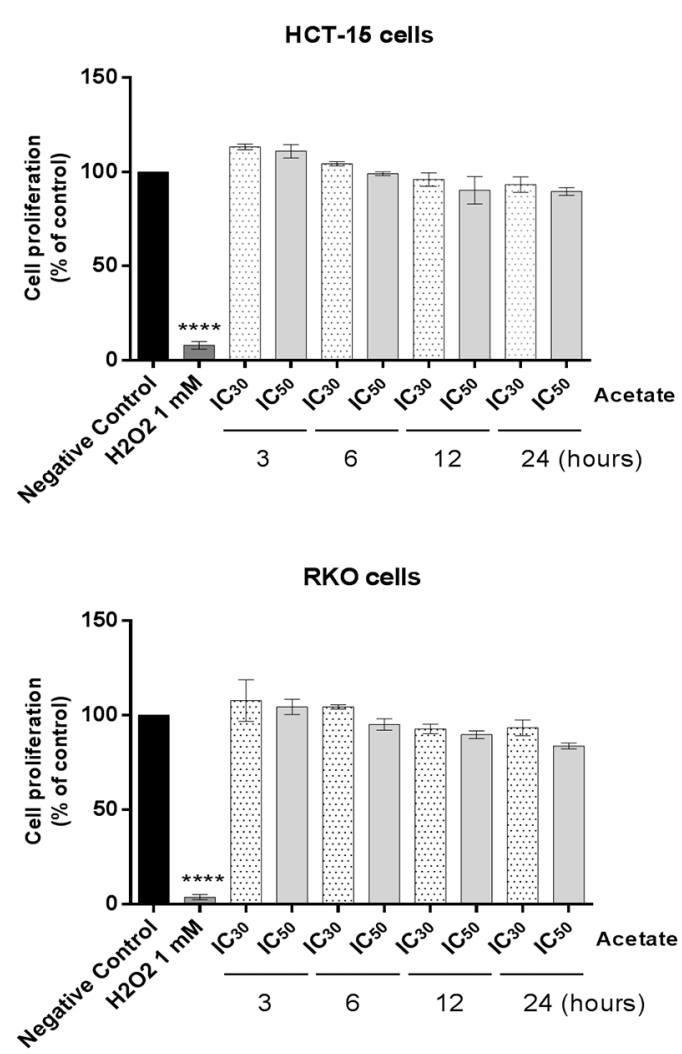

Figure 6: Acetate induces metabolic changes in CRC cells. HCT-15 and RKO cells were incubated with acetate (45 mM and $70 \mathrm{mM}$ for HCT-15 cells; $75 \mathrm{mM}$ and $110 \mathrm{mM}$ for RKO cells, respective doses for the $\mathrm{IC}_{30}$ and $\mathrm{IC}_{50}$ ) or with fresh medium (as negative control). a. Effect of acetate on cell proliferation, determined by SRB assay. HCT- 15 and RKO cells were seeded at a density of $7 \times 10^{4}$ and $5 \times 10^{4}$ cells/well respectively and incubated with sodium acetate $(3,6,12$ and 24 hours). As positive control was used $500 \mathrm{uL}$ and $1 \mathrm{mM}$ $\mathrm{H}_{2} \mathrm{O}_{2}$, respectively for HCT-15 and RKO cells. As negative control cells were incubated with fresh complete medium. For each bar, the mean for at least three independent experiments is represented (Bonferroni's test; ${ }^{* * *} \mathrm{p} \leq 0.001$ compared to control cells). (Continued) 
b

HCT-15

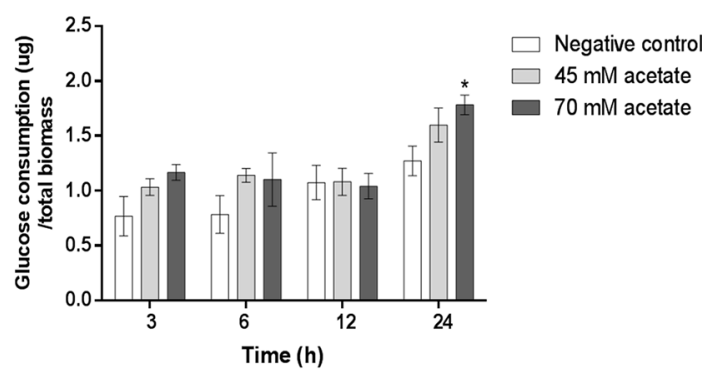

RKO

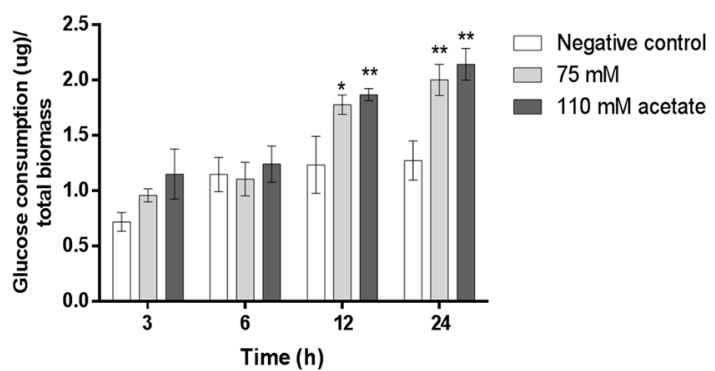

C

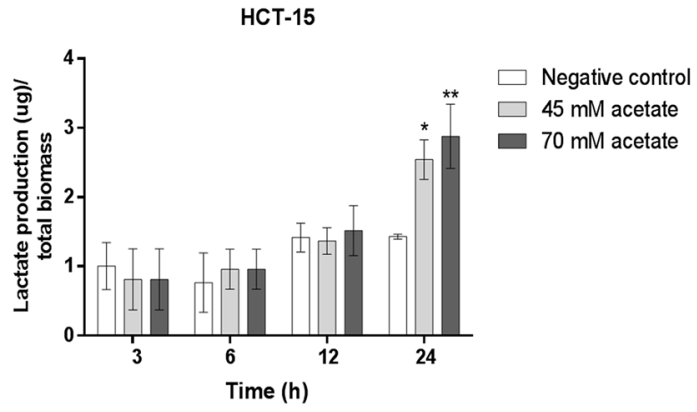

RKO

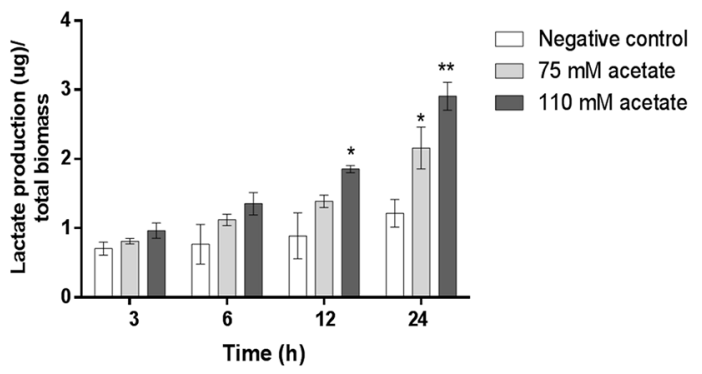

Figure 6: (Continued) Acetate induces metabolic changes in CRC cells. b. Extracellular amounts of glucose consumption and c. lactate production overtimes 3, 6, 12 and 24 hours are shown. Values are expressed as mean $\pm \mathrm{SD}$ of at least three independent experiments. $* \mathrm{P} \leq 0.05$ and $* * \mathrm{P} \leq 0.01$ compared with control cells.

a

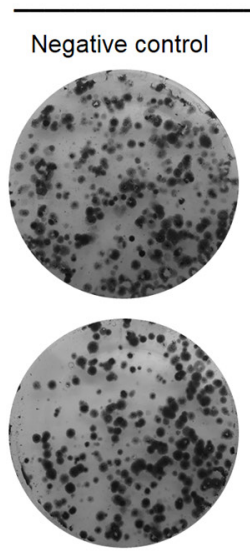

$\mathrm{IC}_{50}$ Acetate
HCT-15
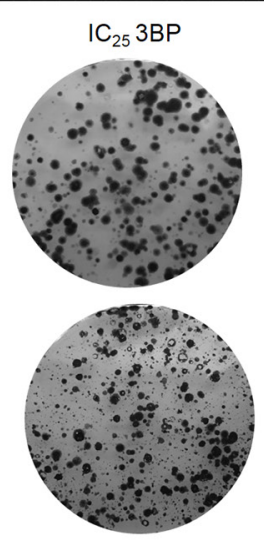

$\mathrm{IC}_{25} 3 \mathrm{BP}+$

$\mathrm{IC}_{50}$ Acetate

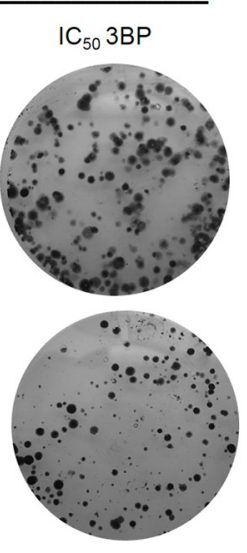

$\mathrm{IC}_{50} 3 \mathrm{BP}+$

$\mathrm{IC}_{50}$ Acetate

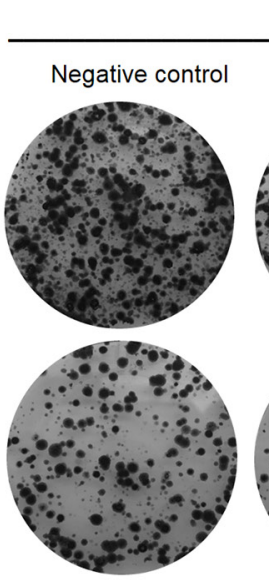

$\mathrm{IC}_{50}$ Acetate
RKO

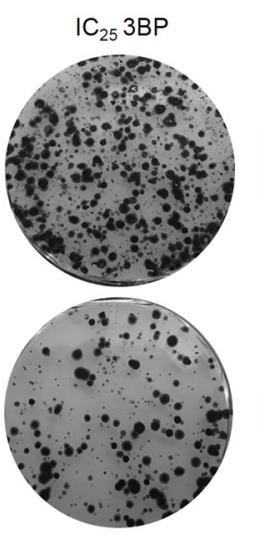

$\mathrm{IC}_{25} 3 \mathrm{BP}+$

$\mathrm{IC}_{50}$ Acetate
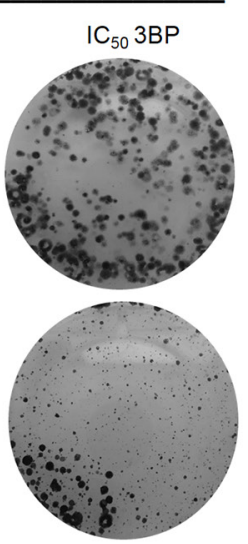

$\mathrm{IC}_{50} 3 \mathrm{BP}+$

$\mathrm{IC}_{50}$ Acetate

Figure 7: Effect of acetate with 3-bromopyruvate (3BP; a glycolysis inhibitor) in CRC cells. a, b and c. CRC cells were treated with $\mathrm{IC}_{25}$ and $\mathrm{IC}_{50}$ values for the $3 \mathrm{BP}(17.5 \mathrm{uM}, 35 \mathrm{uM}$ and $75 \mathrm{uM}, 150 \mathrm{uM}$, respectively for HCT-15 and RKO cells). The treatments were performed with $3 \mathrm{BP}$ alone or with acetate treatment combination (only the $\mathrm{IC}_{50}$ value for the acetate: $70 \mathrm{mM}$ for $\mathrm{HCT}-15$ and 110 $\mathrm{mM}$ for RKO cell line) after $48 \mathrm{~h}$ of incubation. 3BP was added 16 hours before to complete 48 hours of the treatment. As negative control, cells were treated with fresh medium. $\mathrm{H}_{2} \mathrm{O}_{2}(500 \mathrm{uM}$ or $1 \mathrm{mM}$ for HCT-15 or RKO cell lines, respectively) was used as positive control. a. Colony formation assay during 14 days shows that the combined treatment $\left(\mathrm{IC}_{25}\right.$ of $3 \mathrm{BP} / \mathrm{IC}_{50}$ of acetate and $\mathrm{IC}_{50}$ of $3 \mathrm{BP} / \mathrm{IC}{ }_{50}$ of acetate) decreases cell proliferation (number of colony formed at the end of the assay) in both CRC cell lines in a dose-dependent manner compared to the negative control and with the same dose of the 3BP or acetate alone. (Continued) 
b
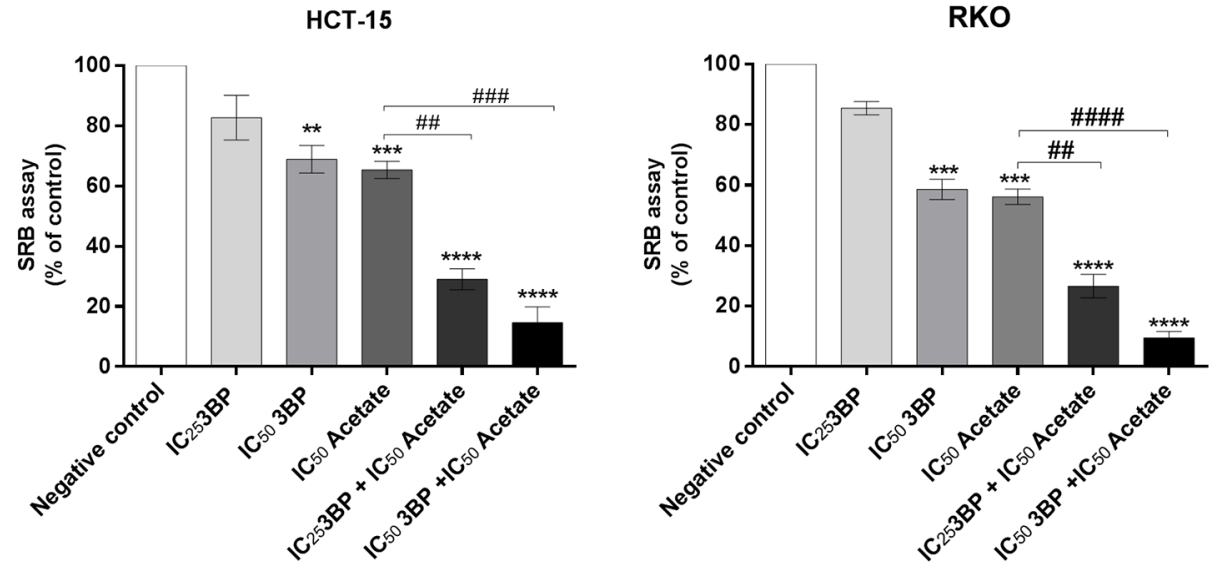

C

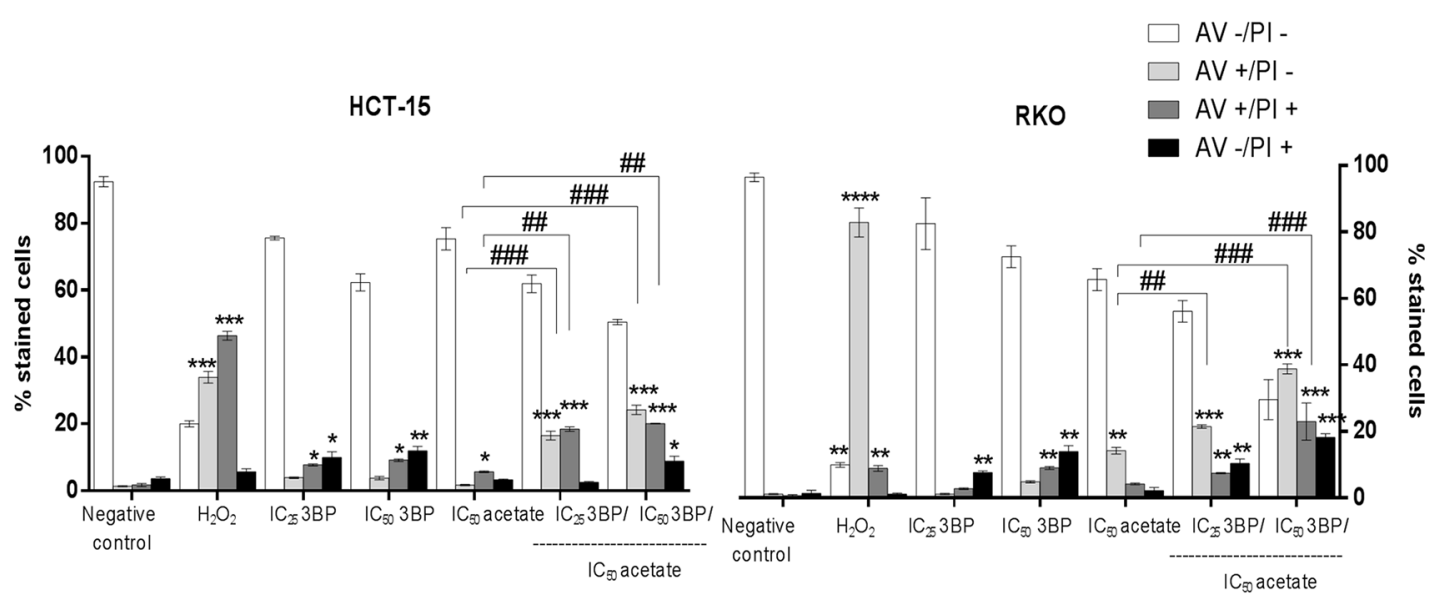

Figure 7: (Continued) Effect of acetate with 3-bromopyruvate (3BP; a glycolysis inhibitor) in CRC cells. a, b and c. b. Sulforhodamine B (SRB) assay analyzes the cell proliferation of the same conditions. Values represent mean \pm SD of at least three independent experiments. ${ }^{*} \mathrm{P} \leq 0.01,{ }^{* * *} \mathrm{P} \leq 0.001$ and ${ }^{* * *} \mathrm{P} \leq 0.0001$ compared with negative control cells and \#\# $\mathrm{P} \leq 0.01$ and \#\#\#\# $\mathrm{P}$ $\leq 0.0001$ comparing acetate alone with combined treatment $\left(\mathrm{IC}_{25}\right.$ of $3 \mathrm{BP} / \mathrm{IC}_{50}$ of acetate and $\mathrm{IC}_{50}$ of $3 \mathrm{BP} / \mathrm{IC}_{50}$ of acetate). c. Quantitative analysis of AV/PI staining in HCT-15 and RKO cells. Values represent mean $\pm \mathrm{SD}(\mathrm{AV}-\mathrm{PI}-, \mathrm{AV}+\mathrm{PI}-, \mathrm{AV}+\mathrm{PI}+$ and $\mathrm{AV}-\mathrm{PI}+$ ) of each condition ( $\mathrm{n}=3$ ). $* \mathrm{P} \leq 0.05,{ }^{*} \mathrm{P} \leq 0.01,{ }^{* * *} \mathrm{P} \leq 0.001$ and $* * * \mathrm{P} \leq 0.0001$ compared with negative control cells and \#\# $\mathrm{P} \leq 0.01$ and \#\#\#\# $\mathrm{P}$ $\leq 0.0001$ comparing acetate alone with combined treatment $\left(\mathrm{IC}_{25}\right.$ of $3 \mathrm{BP} / \mathrm{IC}_{50}$ of acetate and $\mathrm{IC}_{50}$ of $3 \mathrm{BP} / \mathrm{IC}_{50}$ of acetate $)$.

Using the inhibitor AR-C155858, we showed, that MCT1 and/or MCT2 participate actively in the transport of acetate across the membrane in CRC cells exposed to physiological doses of acetate. These observations are in accordance with the transport of butyrate into colon cancer cells mainly by MCT1 [1, 13, 41]. Moreover, MCT1 was also reported to be responsible for acetate transport in mouse cancer cells (Ehrlich-Lettre ascites cells) [42].

Despite some controversies in the literature, MCT1, MCT2 and MCT4 are found upregulated in CRC compared to normal epithelium [15, 43, 44]. There are different mechanisms involved in the regulation of MCTs, however their regulation by SCFA (especially acetate) needed further clarification $[1,12,13,41]$. It has been shown that upon butyrate treatment, MCT1 is the most abundant MCT isoform expressed in the CRC Caco-2 cells [13]. Our data show that exposure to acetate increased the expression of MCT1, MCT4 and the glycosylated CD147, associated with MCT1 re-localization to the plasma membrane of CRC cells. Indeed, MCT1 and MCT4 require association with CD147 for proper plasma membrane localization and function [18]. Our results put forward a possible role of acetate in the regulation of its uptake/transport, both by controlling the expression of MCTs and CD147, with consequent MCT1 functionalization at the plasma membrane in CRC cells. 
Most cancer cells, including CRC, exhibit a hyper-glycolytic phenotype, which is characterized by production of high amounts of lactate, contributing to acidification of the tumor microenvironment $[15,45]$. As glucose becomes the primary source in CRC cells, glucose transporters (GLUTs) and MCTs have a central role in the maintenance of the cancer cell glycolytic metabolism [14, 46]. Here, we observed that acetate induces expression of both MCT1 and MCT4 over time, without changes in the levels of GLUT1, the main glucose transporter expressed in CRC $[16,41,47]$. Furthermore, upon acetate treatment, we observed an increase in glucose consumption and lactate production up to $24 \mathrm{~h}$ in CRC cells, which goes in line with the increased expression of MCTs and the need to export the produced lactate [48-51]. Our findings are in agreement with Matthews et al, describing that butyrate and propionate, alone or in combination, significantly increased glucose consumption. The authors explained the elevated glucose consumption rates, mediated by an increase in oxidative pentose pathway activity (important pathway of glucose metabolism), as a way to produce energy efficiently [6]. In addition, the increase on glucose consumption and lactate production after acetate treatment may be correlated with our previous reports showing that acetate treatment is associated with mitochondria dysfunctions, such as an increase in mitochondrial mass, an accumulation of superoxide anion and a decrease in mitochondrial membrane potential, even after short incubation times (12 and 24 hours after acetate treatment) [9]. The increase in glucose uptake/ consumption by CRC cells after 24 hours of acetate exposure may therefore reflect a response that cells convey to cope with acetate-induced mitochondrial dysfunction and consequently oxidative phosphorylation impairment. Indeed, mitochondria dysfunction induced by acetate might contribute to the observed switch to the glycolytic metabolism up to 24 hours in CRC cells.

Due to MCTs overexpression in cancer and important role in the maintenance of glycolytic metabolism [14, 43], MCTs became attractive targets in cancer therapy, especially in cancers with a hyper-glycolytic phenotype like CRC $[14,46]$. However, they can also be used to transport of drugs into cancer cells, behaving as "Trojan horses" [17, 52]. In fact, MCTs are described to mediate the entry of the chemotherapeutic agent 3BP used to selectively kill cancer cells $[14,17]$. In this context, it was demonstrated that butyrate mediated-increase in MCTs expression and plasma membrane localization sensitizes breast cancer cells to $3 \mathrm{BP}[17,27]$. Since acetate exhibited a similar effect on MCT expression in CRC cells, we hypothesized that acetate could also sensitize CRC cells to 3BP. Our results showed that, in comparison to the effect of acetate or $3 \mathrm{BP}$ alone, the combination of both compounds is more effective in the inhibition of cell proliferation and induction of apoptosis in $\mathrm{CRC}$ cells, which might have important implications in CRC therapy.
Summing up, we show that acetate uptake involves at least two distinct mechanisms of transport in CRC cells namely mediated by SMCT1, MCT1 and/or MCT2 and passive transport by aquaporins. In addition, we found that acetate upregulates MCT1, MCT4 and CD147, with relocalization of MCT1 at the plasma membrane, associated with an increase in the glycolytic phenotype.

Our data showing an important role of MCTs and aquaporins in acetate uptake, consistently with reported data on MCTs and aquaporins overexpression in CRC clinical cases, may underlie acetate selectivity towards CRC cells.

Finally, we identified a novel approach for CRC therapy, based on the elimination of CRC cells exposed to acetate, through their sensitization by $3 \mathrm{BP}$ or another glycolytic inhibitor whose transport is mediated by MCTs.

\section{MATERIALS AND METHODS}

\section{Material}

\section{Reagents}

Sodium acetate and $\mathrm{HgCl}_{2}$ were purchased from Merck. Radiolabelled $\left[{ }^{14} \mathrm{C}\right]$ acetate (specific activity of $55.2 \mathrm{mCi} / \mathrm{mmol}$ ) from PerkinElmer. Carbonyl cyanide m-chlorophenyl hydrazone (CCCP), monensin, valinomycin and $\alpha$-cyano-4-hydroxycinnamic acid (CHC) from Sigma. 4,4'-Di-isothiocyano-2,2'-stilbenedisulfonic acid (DIDS) was obtained from Santa Cruz Biotechnology and AR-C155858 was a gift from AstraZeneca.

\section{Cell lines}

Human colorectal cancer (CRC) cell lines, HCT-15 and RKO were obtained from the American Type Culture Collection (ATCC). Cells were cultured at $37^{\circ} \mathrm{C}$ under a humidified atmosphere containing $5 \% \mathrm{CO}_{2}$. HCT-15 cells were grown in Roswell Park Memorial Institute (RPMI) medium and RKO cells in Dulbecco's Modified Eagle Medium (DMEM).

All culture media were supplemented with $10 \%$ fetal bovine serum and $100 \mathrm{U} / \mathrm{ml}$ penicillin/streptomycin.

\section{Methods}

\section{Acetate uptake assay}

The protocol for $\left[{ }^{14} \mathrm{C}\right]$ acetate uptake used was described previously [17]. For normalization, protein was quantified using a BCA Protein Assay Kit (Pierce). As $\left[{ }^{14} \mathrm{C}\right]$ acetate uptake was linear up to $5 \mathrm{~min}, 3 \mathrm{~min}$ of incubation was used. The effect of inhibitors: ARC155858, CHC, DIDS, CCCP, monensin, valinomycin and $\mathrm{HgCl}_{2}$ was evaluated in cells incubated for $3 \mathrm{~min}$ with each compound in MES buffer, $\mathrm{pH}$ 6.0, prior to incubation with $1.0 \mathrm{mM}\left[{ }^{14} \mathrm{C}\right]$ acetate for $3 \mathrm{~min}$. 


\section{Western blotting assay}

Cells were seeded in 6-well plates and exposed to acetate for 48 hours: $45 \mathrm{mM}, 70 \mathrm{mM}$ for HCT-15 and 75 $\mathrm{mM}, 110 \mathrm{mM}$ for RKO cells $\left(\mathrm{IC}_{30}\right.$ and $\mathrm{IC}_{50}$ acetate doses for both cell lines) previously determined by us [5]. As negative control, cells were incubated with fresh medium. Cell lysis, total protein and Western blotting were carried out as previously described [5].

The primary antibodies used were: anti-MCT1 (1:500), anti-MCT2 (1:200), anti-MCT4 (1:500), antiSMCT1 (1:250), anti-CD147 (1:500), and anti-actin (1:5000), from Santa Cruz Biotechnology; anti-GLUT 1 (1:200) (Abcam). Chemiluminescence was detected using the ECL detection system (Amersham) and the imager Chemi-Doc XRS system (Bio-Rad).

\section{Immunofluorescence assay}

CRC cells were seeded in 12-well plates containing glass coverslips and exposed to acetate during 48 hours $\left(\mathrm{IC}_{30}\right.$ and $\mathrm{IC}_{50}$ acetate doses) for the cellular localization of MCT1, MCT4 and CD147. The immunofluorescence protocol used was described previously [53]. At the end, coverslips were mounted on Vectashield mounting medium with DAPI and observed under a fluorescence microscope (Olympus BX61 fluorescence microscope). Three coverslips were prepared for each experimental condition.

\section{Determination of glucose consumption and lactate production}

Cells cultured in 48-well plates were pre-incubated in glucose-free media for $2 \mathrm{~h}$, cells were washed with PBS and incubated with acetate $\left(\mathrm{IC}_{30}\right.$ and $\mathrm{IC}_{50}$, as mentioned before). Conditioned medium of non-treated cells (negative control) or exposed to acetate was collected at 3, 6, 12 and 24 hours. Glucose consumption and extracellular lactate were measured by the enzymatic colorimetric kits: Glucose Assay Kit (Roche, Mannheim, Germany) and Lactate Assay kit (SpinReact) Fluorescence intensity was detected with absorbance emission at $490 \mathrm{~nm}$. Values are expressed as the mean of fluorescence intensity normalized to T0 (control for glucose and lactate levels before the treatment with acetate) and the cell biomass was analyzed by Sulforhodamine (SRB) assay as previously described [5].

\section{Sulforhodamine (SRB) assay}

The $\mathrm{IC}_{50}$ concentrations of 3-bromopyruvate (3BP) were calculated by the SRB assay as previously described [5]. The following 3BP doses were used: $17.5 \mu \mathrm{M}, 35 \mu \mathrm{M}$ and $75 \mu \mathrm{M}, 150 \mu \mathrm{M} ; \mathrm{IC}_{25}$ and $\mathrm{IC}_{50}$, respectively for HCT15 and RKO cells). For the SRB assay with acetate and 3BP, 3BP was co-incubated 16 hours before completing 48 hours of acetate treatment. Briefly, HCT-15 and RKO were seeded in 24-well and incubated 48 hours with $70 \mathrm{mM}$ and $110 \mathrm{mM}$ of acetate $\left(\mathrm{IC}_{50}\right.$ for HCT-15 and RKO cells, respectively) previously determined [5] with and without previous co-incubation with the $\mathrm{IC}_{25}$ and $\mathrm{IC}_{50}$ doses of $3 \mathrm{BP}$ for $16 \mathrm{~h}$. As negative control cells were incubated with fresh medium and as positive control we used $\mathrm{H}_{2} \mathrm{O}_{2}(500$ $\mathrm{mM}$ or $1 \mathrm{mM}$ for HCT-15 or RKO cell lines, respectively). All samples were measured in triplicates and the values were expressed relative to the negative control.

\section{Colony formation assay (CFA)}

Cells were seeded in 6-well plates at 600 cells/ $\mathrm{mL}, 300$ cells $/ \mathrm{mL}$ (respectively for HCT-15 and RKO cell lines) and were treated as described for the SRB assay (same conditions). After 48 hours of treatment, the medium was replaced by fresh medium twice per week during 14 days. To evaluate the colony numbers formed for each condition, cells were washed with PBS and fixed with $6 \%$ glutaraldehyde $/ 0.5 \%$ crystal violet solution for $30 \mathrm{~min}$, at RT. The cells were then washed with water and air-dried.

\section{Apoptosis assay}

Cells were seeded in 6-well plates and were treated as described above for the SRB assay (same conditions). The percentage of cells undergoing apoptosis after $48 \mathrm{~h}$ of acetate treatment was determined using Annexin-V FITC (AV) (BD Biosciences) and Propidium iodide (PI) (Sigma). Both floating and attached cells were collected and prepared as described previously [5]. Cell viability and cell death was assessed by double staining with Annexin-V FITC/ PI. Unstained and stained cells were classified as follows: viable cells (AV-/PI-), early apoptotic cells (AV+/PI-), late apoptotic cells $(\mathrm{AV}+/ \mathrm{PI}+)$ or necrotic cells $(\mathrm{AV}-\mathrm{PI}+)$.

\section{Statistical analysis}

Kinetic parameters were determined using Prism software version 6 (GraphPad) for the non-linear regression of the values of the initial uptake rates of acetate as a function of the acid concentration. Other statistical significance analysis were determined by twoway ANOVA or one-way ANOVA followed by Dunnett or Bonferroni's test for multiple comparisons. All results are presented as mean \pm standard deviation (SD) of three independent experiments. Differences were considered significant for $P$ values lower than 0.05 .

\section{ACKNOWLEDGMENTS}

This work was supported by Fundação para $a$ Ciência e Tecnologia (FCT) by the FCT-ANR/BEX$\mathrm{BCM} / 0175 / 2012$ and the strategic programme UID/ BIA/04050/2013 (POCI-01-0145-FEDER-007569) funded by national funds through the FCT I.P. and by the ERDF through the COMPETE2020 - Programa Operacional Competitividade e Internacionalização (POCI), as well as by the FCT fellowships: Suellen Ferro (SFRH/BD/77449/2011) and J. Azevedo-Silva (SFRH/ $\mathrm{BD} / 76038 / 2011)$. This work was also supported by the 
Marie Curie Initial Training Network: GLYCOPHARM, PITN-GA-2012-317297. This work was also supported by Projeto Estratégico - LA 26 - 2013-2014 (PEst-C/ SAU/LA0026/2013), Fundo Europeu de Desenvolvimento Regional (FEDER), through COMPETE (FCOMP01-0124-FEDER-037298) and Project "ON.2 SR\&TD Integrated Program (NORTE-07-0124-FEDER-000017)" co-funded by Programa Operacional Regional do Norte (ON.2 - O Novo Norte), Quadro de Referência Estratégico Nacional (QREN), through (FEDER).

We thank AstraZeneca for providing the ARC155858 compound and Young H. Ko (KoDiscovery, USA) and Peter L. Pedersen (John Hopkins University, USA) for providing 3-bromopyruvate.

\section{CONFLICTS OF INTEREST}

The authors declare no conflict of interest.

\section{Authors' contributions}

CSFO performed the majority of the experiments and also wrote the first draft of the manuscript; JAS and $\mathrm{MC}$ designed the transport assay experiments, analyzed and wrote the results. MCR and FB helped in the supervision of the study and revised the manuscript; AP conceived, designed, supervised the study, wrote and revised the manuscript. All authors read and approved the final manuscript.

\section{Abbreviations}

$\mathrm{AV}$, Annexin V; CRC, colorectal cancer; CCCP, carbonyl cyanide m-chlorophenyl hydrazone; CFA, colony formation assay; $\mathrm{CHC}, \alpha$-cyano-hydroxycinnamic acid; DCA, dichloro acetate; DIDS, 4,4'-Di-isothiocyano-2,2'stilbenedisulfonic acid; IC, inhibitory concentration; MCT, monocarboxylate transporter, PI, Propidium iodide; RT, room temperature, SCFA, short-chain fatty acids; SRB, sulforhodamine B, 3BP, 3-bromopyruvate.

\section{REFERENCES}

1. Goncalves P and Martel F. Butyrate and colorectal cancer: the role of butyrate transport. Current drug metabolism. 2013; 14:994-1008.

2. Zeng $\mathrm{H}$, Lazarova DL and Bordonaro M. Mechanisms linking dietary fiber, gut microbiota and colon cancer prevention. World journal of gastrointestinal oncology. 2014; 6:41-51.

3. Lan A, Bruneau A, Philippe C, Rochet V, Rouault A, Herve C, Roland N, Rabot S and Jan G. Survival and metabolic activity of selected strains of Propionibacterium freudenreichii in the gastrointestinal tract of human microbiota-associated rats. The British journal of nutrition. 2007; 97:714-724.
4. Lan A, Bruneau A, Bensaada M, Philippe C, Bellaud P, Rabot S and Jan G. Increased induction of apoptosis by Propionibacterium freudenreichii TL133 in colonic mucosal crypts of human microbiota-associated rats treated with 1,2-dimethylhydrazine. The British journal of nutrition. 2008; 100:1251-1259.

5. Marques C, Oliveira CS, Alves S, Chaves SR, Coutinho OP, Corte-Real M and Preto A. Acetate-induced apoptosis in colorectal carcinoma cells involves lysosomal membrane permeabilization and cathepsin D release. Cell death \& disease. 2013; 4:e507.

6. Matthews GM, Howarth GS and Butler RN. Short-chain fatty acids induce apoptosis in colon cancer cells associated with changes to intracellular redox state and glucose metabolism. Chemotherapy. 2012; 58:102-109.

7. Sengupta S, Muir JG and Gibson PR. Does butyrate protect from colorectal cancer? Journal of gastroenterology and hepatology. 2006; 21:209-218.

8. Scheppach W, Bartram HP and Richter F. Role of shortchain fatty acids in the prevention of colorectal cancer. Eur J Cancer. 1995; 31A:1077-1080.

9. Oliveira CS, Pereira H, Alves S, Castro L, Baltazar F, Chaves SR, Preto A and Corte-Real M. Cathepsin D protects colorectal cancer cells from acetate-induced apoptosis through autophagy-independent degradation of damaged mitochondria. Cell death \& disease. 2015; 6:e1788.

10. Nedjadi T, Moran AW, Al-Rammahi MA and ShiraziBeechey SP. Characterization of butyrate transport across the luminal membranes of equine large intestine. Experimental physiology. 2014; 99:1335-1347.

11. Kim CH, Park J and Kim M. Gut microbiota-derived short-chain Fatty acids, T cells, and inflammation. Immune network. 2014; 14:277-288.

12. Ganapathy V, Thangaraju M, Prasad PD, Martin PM and Singh N. Transporters and receptors for short-chain fatty acids as the molecular link between colonic bacteria and the host. Current opinion in pharmacology. 2013; 13:869-874.

13. Hadjiagapiou C, Schmidt L, Dudeja PK, Layden TJ and Ramaswamy K. Mechanism(s) of butyrate transport in Caco-2 cells: role of monocarboxylate transporter 1 . American journal of physiology Gastrointestinal and liver physiology. 2000; 279:G775-780.

14. Baltazar F, Pinheiro C, Morais-Santos F, Azevedo-Silva J, Queiros O, Preto A and Casal M. Monocarboxylate transporters as targets and mediators in cancer therapy response. Histology and histopathology. 2014; 29:1511-1524.

15. Pinheiro C, Longatto-Filho A, Azevedo-Silva J, Casal M, Schmitt FC and Baltazar F. Role of monocarboxylate transporters in human cancers: state of the art. Journal of bioenergetics and biomembranes. 2012; 44:127-139.

16. Amorim R, Pinheiro C, Miranda-Goncalves V, Pereira H, Moyer MP, Preto A and Baltazar F. Monocarboxylate transport inhibition potentiates the cytotoxic effect of 
5-fluorouracil in colorectal cancer cells. Cancer letters. 2015; 365:68-78.

17. Azevedo-Silva J, Queiros O, Ribeiro A, Baltazar F, Young KH, Pedersen PL, Preto A and Casal M. The cytotoxicity of 3-bromopyruvate in breast cancer cells depends on extracellular pH. The Biochemical journal. 2015; 467:247-258.

18. Halestrap AP and Meredith D. The SLC16 gene familyfrom monocarboxylate transporters (MCTs) to aromatic amino acid transporters and beyond. Pflugers Archiv : European journal of physiology. 2004; 447:619-628.

19. Paroder V, Spencer SR, Paroder M, Arango D, Schwartz S, Jr., Mariadason JM, Augenlicht LH, Eskandari S and Carrasco N. $\mathrm{Na}(+) /$ monocarboxylate transport (SMCT) protein expression correlates with survival in colon cancer: molecular characterization of SMCT. Proceedings of the National Academy of Sciences of the United States of America. 2006; 103:7270-7275.

20. Wilson MC, Meredith D, Bunnun C, Sessions RB and Halestrap AP. Studies on the DIDS-binding site of monocarboxylate transporter 1 suggest a homology model of the open conformation and a plausible translocation cycle. The Journal of biological chemistry. 2009; 284:20011-20021.

21. Ovens MJ, Davies AJ, Wilson MC, Murray CM and Halestrap AP. AR-C155858 is a potent inhibitor of monocarboxylate transporters MCT1 and MCT2 that binds to an intracellular site involving transmembrane helices 7-10. The Biochemical journal. 2010; 425:523-530.

22. Papadopoulos MC and Saadoun S. Key roles of aquaporins in tumor biology. Biochimica et biophysica acta. 2014; 1848:2576-2583.

23. Hirano Y, Okimoto N, Kadohira I, Suematsu M, Yasuoka K and Yasui M. Molecular mechanisms of how mercury inhibits water permeation through aquaporin-1: understanding by molecular dynamics simulation. Biophysical journal. 2010; 98:1512-1519.

24. Wang J, Feng L, Zhu Z, Zheng M, Wang D, Chen Z and Sun H. Aquaporins as diagnostic and therapeutic targets in cancer: how far we are? Journal of translational medicine. 2015; 13:2-11.

25. Yukutake Y, Tsuji S, Hirano Y, Adachi T, Takahashi T, Fujihara K, Agre P, Yasui M and Suematsu M. Mercury chloride decreases the water permeability of aquaporin-4reconstituted proteoliposomes. Biology of the cell / under the auspices of the European Cell Biology Organization. 2008; 100:355-363.

26. Zhang TB, Zhao Y, Tong ZX and Guan YF. Inhibition of glucose-transporter 1 (GLUT-1) expression reversed Warburg effect in gastric cancer cell MKN45. International journal of clinical and experimental medicine. 2015; 8:2423-2428.
27. Queiros O, Preto A, Pacheco A, Pinheiro C, Azevedo-Silva J, Moreira R, Pedro M, Ko YH, Pedersen PL, Baltazar F and Casal M. Butyrate activates the monocarboxylate transporter MCT4 expression in breast cancer cells and enhances the antitumor activity of 3-bromopyruvate. Journal of bioenergetics and biomembranes. 2012; 44:141-153.

28. Zhu Y, Michelle Luo T, Jobin C and Young HA. Gut microbiota and probiotics in colon tumorigenesis. Cancer letters. 2011; 309:119-127.

29. Cipe G, Idiz UO, Firat D and Bektasoglu H. Relationship between intestinal microbiota and colorectal cancer. World journal of gastrointestinal oncology. 2015; 7:233-240.

30. Topping DL and Clifton PM. Short-chain fatty acids and human colonic function: roles of resistant starch and nonstarch polysaccharides. Physiological reviews. 2001; 81:1031-1064.

31. Jan G, Belzacq AS, Haouzi D, Rouault A, Metivier D, Kroemer $G$ and Brenner C. Propionibacteria induce apoptosis of colorectal carcinoma cells via short-chain fatty acids acting on mitochondria. Cell death and differentiation. 2002; 9:179-188.

32. Iwanaga T, Takebe K, Kato I, Karaki S and Kuwahara A. Cellular expression of monocarboxylate transporters (MCT) in the digestive tract of the mouse, rat, and humans, with special reference to slc5a8. Biomed Res. 2006; 27:243-254.

33. Miyauchi S, Gopal E, Fei YJ and Ganapathy V. Functional identification of SLC5A8, a tumor suppressor downregulated in colon cancer, as a $\mathrm{Na}(+)$-coupled transporter for short-chain fatty acids. The Journal of biological chemistry. 2004; 279:13293-13296.

34. Thangaraju M, Cresci G, Itagaki S, Mellinger J, Browning DD, Berger FG, Prasad PD and Ganapathy V. Sodiumcoupled transport of the short chain fatty acid butyrate by SLC5A8 and its relevance to colon cancer. Journal of gastrointestinal surgery : official journal of the Society for Surgery of the Alimentary Tract. 2008; 12:1773-1781; discussion 1781-1772.

35. Thangaraju M, Karunakaran SK, Itagaki S, Gopal E, Elangovan S, Prasad PD and Ganapathy V. Transport by SLC5A8 with subsequent inhibition of histone deacetylase 1 (HDAC1) and HDAC3 underlies the antitumor activity of 3-bromopyruvate. Cancer. 2009; 115:4655-4666.

36. Babu E, Ramachandran S, CoothanKandaswamy V, Elangovan S, Prasad PD, Ganapathy V and Thangaraju M. Role of SLC5A8, a plasma membrane transporter and a tumor suppressor, in the antitumor activity of dichloroacetate. Oncogene. 2011; 30:4026-4037.

37. Li H, Myeroff L, Smiraglia D, Romero MF, Pretlow TP, Kasturi L, Lutterbaugh J, Rerko RM, Casey G, Issa JP, Willis J, Willson JK, Plass C and Markowitz SD. SLC5A8, a sodium transporter, is a tumor suppressor gene silenced by methylation in human colon aberrant crypt foci and cancers. Proc Natl Acad Sci U S A. 2003; 100:8412-8417. 
38. Verkman AS. More than just water channels: unexpected cellular roles of aquaporins. Journal of cell science. 2005; 118:3225-3232.

39. Verkman AS. Novel roles of aquaporins revealed by phenotype analysis of knockout mice. Reviews of physiology, biochemistry and pharmacology. 2005; 155:31-55.

40. Nagaraju GP, Basha R, Rajitha B, Alese OB, Alam A, Pattnaik S and El-Rayes B. Aquaporins: Their role in gastrointestinal malignancies. Cancer letters. 2016; 373:8-12.

41. He L, Li X, Luo HS, Rong H and Cai J. Possible mechanism for the regulation of glucose on proliferation, inhibition and apoptosis of colon cancer cells induced by sodium butyrate. World journal of gastroenterology : WJG. 2007; 13:4015-4018.

42. Carpenter L and Halestrap AP. The kinetics, substrate and inhibitor specificity of the lactate transporter of Ehrlich-Lettre tumour cells studied with the intracellular $\mathrm{pH}$ indicator BCECF. The Biochemical journal. 1994; 304:751-760.

43. Pinheiro C, Reis RM, Ricardo S, Longatto-Filho A, Schmitt F and Baltazar F. Expression of monocarboxylate transporters 1, 2, and 4 in human tumours and their association with CD147 and CD44. Journal of biomedicine \& biotechnology. 2010; 2010:427694.

44. Pinheiro C, Longatto-Filho A, Scapulatempo C, Ferreira L, Martins S, Pellerin L, Rodrigues M, Alves VA, Schmitt F and Baltazar F. Increased expression of monocarboxylate transporters 1, 2, and 4 in colorectal carcinomas. Virchows Archiv : an international journal of pathology. 2008; 452:139-146.

45. Vander Heiden MG, Cantley LC and Thompson CB. Understanding the Warburg effect: the metabolic requirements of cell proliferation. Science. 2009; 324:1029-1033.
46. Halestrap AP. The SLC16 gene family - structure, role and regulation in health and disease. Molecular aspects of medicine. 2013; 34:337-349.

47. Lambert DW, Wood IS, Ellis A and Shirazi-Beechey SP. Molecular changes in the expression of human colonic nutrient transporters during the transition from normality to malignancy. British journal of cancer. 2002; 86:1262-1269.

48. Moschen I, Broer A, Galic S, Lang F and Broer S. Significance of short chain fatty acid transport by members of the monocarboxylate transporter family (MCT). Neurochemical research. 2012; 37:2562-2568.

49. Kasubuchi M, Hasegawa S, Hiramatsu T, Ichimura A and Kimura I. Dietary gut microbial metabolites, short-chain fatty acids, and host metabolic regulation. Nutrients. 2015; 7:2839-2849.

50. Jaworski DM, Namboodiri AM and Moffett JR. Acetate as a Metabolic and Epigenetic Modifier of Cancer Therapy. Journal of cellular biochemistry. 2015; 117:574-588.

51. Long PM, Tighe SW, Driscoll HE, Fortner KA, Viapiano MS and Jaworski DM. Acetate supplementation as a means of inducing glioblastoma stem-like cell growth arrest. Journal of cellular physiology. 2015; 230:1929-1943.

52. Pedersen PL. 3-Bromopyruvate (3BP) a fast acting, promising, powerful, specific, and effective "small molecule" anti-cancer agent taken from labside to bedside: introduction to a special issue. Journal of bioenergetics and biomembranes. 2012; 44:1-6.

53. Pinheiro C, Penna V, Morais-Santos F, Abrahao-Machado LF, Ribeiro G, Curcelli EC, Olivieri MV, Morini S, Valenca I, Ribeiro D, Schmitt FC, Reis RM and Baltazar F. Characterization of monocarboxylate transporters (MCTs) expression in soft tissue sarcomas: distinct prognostic impact of MCT1 sub-cellular localization. Journal of translational medicine. 2014; 12:118. 